\title{
PEMETAAN HABITAT PERAIRAN DANGKAL DI KAWASAN PADAT WISATA TANJUNG BENOA BALI MENGGUNAKAN DATA REMOTE SENSING
}

\author{
I Wayan Gede Astawa Karang, ${ }^{1,2}$, I Dewa Made Krisna Putra Astaman ${ }^{1,2)}$, I Wayan \\ Matsya Deva Nagendra ${ }^{1,2)}$,I Gede Hendrawan ${ }^{1)}$ \\ ${ }^{1)}$ Program Studi Ilmu Kelautan, Fakultas Kelautan dan Perikanan, Universitas Udayana \\ ${ }^{2)}$ Laboratorium GIS dan Remote Sensing, Fakultas Kelautan dan Perikanan, Universitas Udayana \\ *Email: gedekarang@unud.ac.id
}

\section{MAPPING SHALLOW WATER HABITAT IN TANJUNG BENOA TOURISM AREA BALI USING REMOTE SENSING DATA}

\begin{abstract}
Most of the tourism area are distributed along the coast that intersects directly with those that result in degradation of the ecosystem inside. The southern region of Bali is one region that have experienced rapid development of tourism activities. The expansion of the tourism area in Tanjung Benoa, Bali occurs to coastal areas and directly contact with underwater habitat such as coral reefs and seagrass beds which can damage the underwater ecosystem. The goal of this study is to map shallow water habitat in densely packed tourist areas Tanjung Benoa, Bali using remote sensing technique. Two satellites dataset (Sentinel-2A and Landsat 8) at different spatial and spectral resolutions were tested using Lyzenga algorithm. The maksimun likehood supervised classification is used to classify the underwater objects and accuracy test were then conducted to to evaluate the classification effectiveness. The results showed that there were three types of shallow water habitats in Tanjung Benoa coastal area, such as dead coral, seagrass, and sand. The accuracy test showed Sentinel-2A images with an overall accuracy of $80,00 \%$ and kappa accuracy of $59.27 \%$. had higher accuracy than Landsat 8 images with an overall accuracy of $68,29 \%$ and kappa accuracy of $35,43 \%$.
\end{abstract}

Keywords: Remote Sensing, Shallow Water Habitat, Tanjung Benoa, Sentinel-2A; Landsat 8

\section{PENDAHULUAN}

Perkembangan industri pariwisata di Indonesia mengalami peningkatan yang pesat dalam kurun waktu 10 tahun terakhir terutama pada wisata bahari (Khrisnamurti dkk., 2016). Sebagian besar objek wisata yang padat pengunjung terdistribusi di wilayah pesisir yang bersinggungan langsung dengan ekosistem perairan dangkal seperti padang lamun dan terumbu karang yang mengakibatkan terjadinya degradasi terhadap kuantitas dan kualitas ekosistem yang ada di dalamnya (Graha dkk., 2016). Seperti halnya ekosistem di darat, ekosistem perairan juga memiliki daya hemostasis dalam mempertahankan keseimbangan ekosistem dan daya dukung (carrying capacity) serta kemampuan untuk memurnikan diri (self purification) dari bentuk gangguan luar yang masuk ke dalam lingkungan perairan (Putra dan Husrin, 2017). Beban yang melampaui daya hemostasis mengakibatkan adanya gangguan keseimbangan yang bermuara pada turunnya kualitas perairan (Darmono, 2001). Beberapa penelitian telah melaporkan terjadinya degradasi pada beberapa ekosistem perairan seperti kondisi produktivitas hutan mangrove di Delta Mahakam yang menurun akibat alih fungsi lahan menjadi tambah 
(Adisuksma dkk., 2014). Khrisnamurti dkk. (2016), menyatakan pembuangan limbah dan tumpukan sampah di Kepulauan Seribu menyebabkan turunnya kualitas perairan di kawasan tersebut.

Pulau Bali memiliki ekosistem perairan dengan tingkat keanekaragaman yang tinggidan telah banyak dimanfaatkan sebagai tujuan pariwisata. Pesisir Tanjung Benoa terletak di bagian selatan Pulau Bali merupakan daerah yang mengalami perkembangan pesat di wilayah pesisirnya dengan aktivitas wisata airnya. Menurut Badan Pusat Statistik Provinsi Bali, jumlah kunjungan wisatawan asing ke Bali pada tahun 2018 sebanyak 6.070.473 dengan pertumbuhan sebesar 6.54\% (BPS, 2018). Ekspansi daerah pariwisata di Tanjung Benoa terjadi sampai ke area perairan yang bersentuhan langsung dengan ekosistem bawah air seperti padang lamun dan terumbu karang yang berdampak terhadap perubahan luasan ekosistem tersebut. Beberapa kawasan pesisir selatan Bali telah mengalami degradasi ekosistem, seperti yang dilaporkan oleh Putra dan Husrin (2017), menunjukkan kualitas air di Pantai Kuta telah mencapai ambang batas yang ditetapkan. Faiqoh dkk. (2017) menyatakan terjadi penurunan kelimpahan ikan di Pantai Samuh akibat berkurangnya padang lamun dan; Rahadiarta dkk. (2019), menyatakan terjadi penurunan luasan area padang lamun yang diakibatkan oleh pembangunan sarana pariwisata yang berdampak terhadap penyerapan karbon di Pantai Mengiat. Penelitian diatas menunjukkan telah terjadi penurunan ekosistem yang diakibatkan berbagai kegiatan pariwisata tanpa strategi kebijakan yang tepat.

Informasi mengenai pola distribusi objek bawah air perairan laut dangkal dapat menjadi langkah awal dalam pengambilan keputusan dan kebijakan dalam pengelolaan pariwisata berbasis ekologi. Sejauh ini, penelitian tentang persebaran dan distribusi objek bawah air di kawasan pesisir selatan Bali masih sedikit khususnya informasi habitat perairan dangkal berbasis data spasial. Apabila tidak diiringi dengan pembaharuan informasi gambaran objek perairan maka semakin besar kemungkinan dampak negatif yang dapat mempengaruhi habitat dan ekosistem yang ada didalamnya (Bato dkk., 2013). Pendeteksian habitat dasar perairan laut dangkal memerlukan metode yang cepat dan tepat dengan mengacu ke dalam skala spasial dan temporal. Kemajuan teknologi seperti penginderaan jauh telah membuktikan penginderaan jauh dapat digunakan sebagai alternatif yang paling ideal untuk pendeteksian habitat dasar perairan. Sensor yang dibawa oleh wahana penginderaan jauh memiliki kemampuan untuk mendeteksi berbagai karakteristik ekosistem perairan laut dangkal (Siregar, 2010).

Citra satelit dapat dimanfaatkan untuk deteksi objek perairan laut dangkal.Citra satelit seperti Landsat, Aster, ALOS-AVNIR, Quickbird dan Wordview telah banyak digunakan dalam pemetaan wilayah baik darat maupun perairan. Beberapa penelitian terkait pemetaan objek bawah air memanfaatkan teknologi penginderaan jauh antara lain, Nurdin dkk. (2016), melakukan pemetaan berbagai objek di bawah permukaan pada perairan laut dangkal menunjukkan citra ALOS AVNIR-2 dapat membedakan 10 tutupan objek. Sedangkan Suwargana (2014) dan Arief (2013), berhasil menggunakan citra ALOS AVNIR-2 untuk pemetaan habitat terumbu karang secara spesifik. Namun demikian salah satu pembatas pemanfaatan satelit optik resolusi tinggi adalah rendahnya resolusi temporal dan biaya yang mahal karena berbayar atau tidak bersifat open source. Satelit Sentinel-2A merupakan satelit generasi baru yang dirancang oleh European Space Agency (ESA) untuk observasi bumi yang keseluruhan datanya dapat diakses secara bebas seperti halnya citra Landsat. Satelit Sentinel-2A memiliki resolusi spasial sebesar 10 meter dan membawa 13 band yang disebut sebagai platform multispectral instrument (MSI) yang dapat digunakan sebagai solusi pemetaan objek perairan laut dangkal dengan kelebihan pada resolusi serta. Penelitian ini bertujuan untuk mengetahui efektivitas citra Sentinel-2A dan Landsat 8 
untuk memetakan objek bawah air laut dangkal di kawasan padat wisata Tanjung Benoa, Bali.

\section{METODOLOGI}

\subsection{Lokasi Penelitian}

Lokasi penelitian adalah perairan dangkal pesisir Tanjung Benoa yang berada di wilayah pesisir Bali bagian selatan, yakni terbentang antara $8^{\circ} 49^{\prime} 15^{\prime \prime}-8^{\circ} 45^{\prime} 00^{\prime}$ ' LS

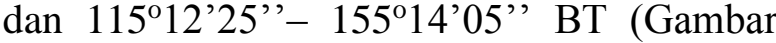
1).Posisi perairan Tanjung Benoa sangat strategis karena kondisi hidrografinya dipengaruhi oleh perairan Selat Lombok dan Samudra Hindia. Aliran massa air dari dua sumber tersebut sangat berperan pada eksistensi ekosistem di perairan Tanjung Benoa.

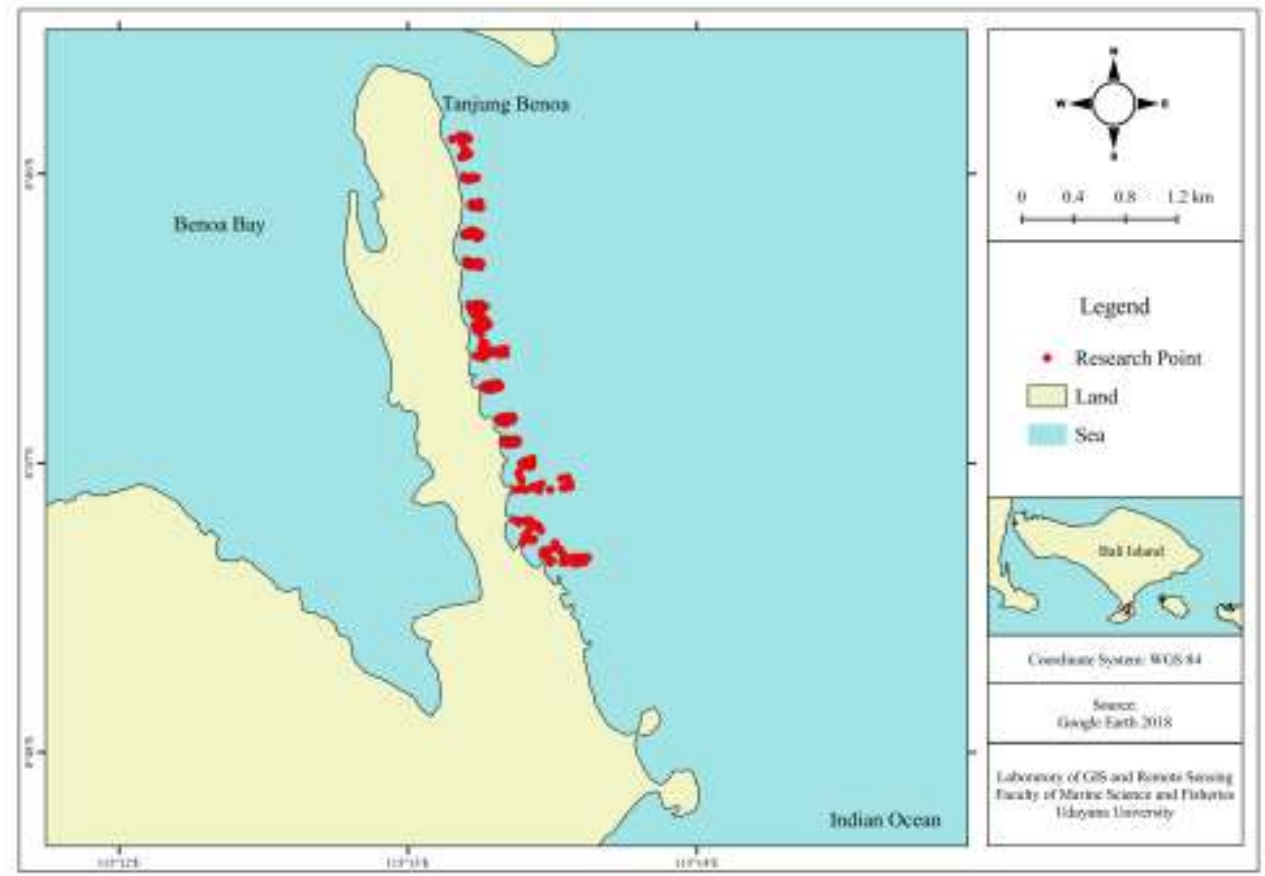

Gambar 1.

Peta Lokasi dan Pengamatan Titik Penelitian

\subsection{Alat dan Data}

Pengambilan data lapangan berupa substrat dasar perairan dangkal menggunakan transek kuadran $1 \mathrm{~m} \times 1 \mathrm{~m}$ dan Global Possition System (GPS). Data diolah dengan komputer DELL RAM $8 \mathrm{~GB}$, software SAGA-GIS versi 5.0.0 dan software QGIS Desktop versi 2.18.2.Data satelit yang digunakan adalah data citra satelit Landsat 8 level 1T akuisisi 5 Juni 2018 yang diunduh melalui web https://earthexplorer.usgs.govdan satelit Sentinel-2A level 1C akuisisi 17 Juni 2018 yang diunduh melalui web https://scihub.copernicus.eu.Citra Landsat 8 dan Sentinel-2A merupakan citra satelit open sourcedengan karakteristik sensor yang berbeda (Tabel 1).

Tabel 1. Karakteristik Citra Landsat 8 dan Sentinel-2A

\begin{tabular}{|c|c|c|c|c|c|}
\hline \multicolumn{3}{|c|}{ Landsat 8} & \multicolumn{3}{|c|}{ Sentinel-2A } \\
\hline Nama Band & $\begin{array}{c}\text { Panjang } \\
\text { Gelombang } \\
(\mu \mathrm{m})\end{array}$ & $\begin{array}{l}\text { Resolusi } \\
\text { (m) }\end{array}$ & Nama Band & $\begin{array}{c}\text { Panjang } \\
\text { Gelombang } \\
(\mu \mathrm{m})\end{array}$ & $\begin{array}{l}\text { Resolusi } \\
\text { (m) }\end{array}$ \\
\hline $\begin{array}{c}\text { Band 1Coastal } \\
\text { Aerosol }\end{array}$ & $0.435-0.451$ & 30 & $\begin{array}{c}\text { Band } 1 \text { Coastal } \\
\text { Aerosol }\end{array}$ & 0.443 & 60 \\
\hline Band 2 Blue & $0.452-0.512$ & 30 & Band 2 Blue & 0.490 & 10 \\
\hline
\end{tabular}




\begin{tabular}{|c|c|c|c|c|c|}
\hline \multicolumn{3}{|c|}{ Landsat 8} & \multicolumn{3}{|c|}{ Sentinel-2A } \\
\hline Band 3 Green & $0.533-0.590$ & 30 & Band 3 Green & 0.560 & 10 \\
\hline Band 4 Red & $0.636-0.673$ & 30 & Band 4 Red & 0.665 & 10 \\
\hline Band 5 NIR & $0.851-0.879$ & 30 & $\begin{array}{c}\text { Band } 5 \text { Vegetation } \\
\text { Red Edge }\end{array}$ & 0.705 & 20 \\
\hline Band 6 SWIR-1 & $1.566-1.651$ & 30 & $\begin{array}{c}\text { Band } 6 \text { Vegetation } \\
\text { Red Edge }\end{array}$ & 0.740 & 20 \\
\hline Band 7 SWIR-2 & $2.107-2.294$ & 30 & $\begin{array}{c}\text { Band } 7 \text { Vegetation } \\
\text { Red Edge }\end{array}$ & 0.783 & 20 \\
\hline Band 8 Pankromatik & $0.503-0.676$ & 15 & Band 8 NIR & 0.842 & 10 \\
\hline Band 9 Cirrus & $1.363-1.384$ & 30 & $\begin{array}{c}\text { Band 8b Vegetation } \\
\text { Red Edge }\end{array}$ & 0.865 & 20 \\
\hline Band 10 TIRS-1 & $10.60-11.19$ & 100 & $\begin{array}{c}\text { Band } 9 \text { Water } \\
\text { Vapour }\end{array}$ & 0.945 & 60 \\
\hline \multirow[t]{3}{*}{ Band 11 TIRS-2 } & $11.50-12.51$ & 100 & $\begin{array}{c}\text { Band } 10 \text { SWIR- } \\
\text { Cirrus }\end{array}$ & 1.380 & 60 \\
\hline & & & Band 11 SWIR & 1.610 & 20 \\
\hline & & & Band 12 SWIR & 2.190 & 20 \\
\hline & & & & \multicolumn{2}{|c|}{10 hari (satelit tunggal) } \\
\hline Resolusi Temporal & 16 hari & & Resolusi Temporal & \multicolumn{2}{|c|}{$\begin{array}{l}5 \text { hari (konstelasi } \\
\text { gabungan) }\end{array}$} \\
\hline $\begin{array}{c}\text { Resolusi } \\
\text { Radiometrik }\end{array}$ & \multicolumn{2}{|l|}{16 bit } & Resolusi Radiometrik & \multicolumn{2}{|c|}{12 bit } \\
\hline
\end{tabular}

\subsection{Metode Penelitian}

Metode penelitian terdiri atas 1) Pra Pngolahan Citra; 2) Pengolahan Citra; 3) Klasifikasi Citra; 4) Uji Akurasi dengan rincian sebagai berikut:

\section{A. Pra Pengolahan Citra}

Tahapan pra pengolahan citra meliputi koreksi atmosferik, pemotongan citra (cropping), dan masking citra. Koreksi atmosferik bertujuan untuk mempertajam citra dengan mengeliminasi gangguan hamburan atmosfer. Metode Dark Object Subtraction (DOS) dengan tool SemiAutomatic Classification yang terdapat pada software QGIS (Congedo, 2016) digunakan untuk mengoreksi objek gelap (Dark Object Substraction) dan mendapatkan nilai reflektan.

Setelah koreksi atmosferik dilakukan pemotongan citra atau cropping untuk fokus pada daerah penelitian. Proses cropping berdampak pada ukuran file yang mengecil sehingga mempercepat proses pengolahan berikutnya. Pemotongan citra dilakukan pada wilayah pesisir kawasan Tanjung Benoa, Bali. Citra yang telah terkoreksi atmosferik dan cropping kemudian dilanjutkan dengan proses masking citra atau pemisahan antara objek pada daerah kajian dengan bukan daerah kajian dalam satu citra. Pada penelitian ini daratan atau pulau merupakan area yang dipisahkan dari perairan karena klasifikasi hanya pada perairan dangkal. Proses pemisahan darat dan perairan menggunakan metode NDWI (Normalized Difference Water Index). Adapun persamaan NDWI menurut McFeeters (2013) yang dapat dilihat pada persamaan (1).

$$
\text { NDWI }=\frac{\text { Green }-N I R}{\text { Green }+N I R}
$$

Dimana Green adalah citra band hijau atau band 3 untuk citra Landsat 8 dan Sentinel-2A; NIR adalah citra band Near Infrared atau band 5 untuk citra Landsat 8 dan band 8 untuk citra Sentinel-2A.

\section{B. Pengolahan Citra}

Proses pengolahan citra terdiri atas penyusunan citra komposit, koreksi kolom air dengan analisis Lyzenga, dan klasifikasi citra 
dengan perincian sebagai berikut: (1) Penyusunan citra komposit dengan komposisi beberapa band untuk memperoleh pewarnaan RGB (Red-Green-Blue) sealami mungkin. Pada penelitian ini komposit citra yang digunakan yaitu komposit warna asli (true color composite). Menurut BIG (2014) komposit warna asli (true color composite) merupakan komposit yang direkomendasikan untuk identifikasi habitat perairan dangkal dengan kemampuan penetrasi ke dalam air jernih yang cukup bagus, namun salah satu kelemahannya adalah tingkat gangguan atmosferik yang tinggi. (2) Koreksi kolom air bertujuan untuk mendapatkan informasi objek dibawah permukaan air yang sudah bebas dari pengrauh kedalaman air, kekeruhan, dan pergerakan muka air dengan membuat citra baru dari Depth Invariant Index (DII) (Lyzenga, 1981). DII dibentuk dengan kombinasi band sinar tampak dari citra Landsat 8 dan Sentinel-2A. Adapun persamaan yang digunakan, yaitu sebagai berikut (Lyzenga, 1981).

Depth Invariant Index band $_{i j}=$

$\ln \left(L_{i}\right)-\left[\left(\frac{k_{i}}{k_{j}}\right) \ln \left(L_{j}\right)\right]$

$\frac{k_{i}}{k_{j}}=a+\sqrt{a^{2}+1}$

Nilai $a$ ditentukan dari persamaan (4).

$a=\frac{\left(\sigma_{i i}-\sigma_{j j}\right)}{2 \times \sigma_{i j}}$

Dimana $L_{i}$ adalah nilai reflektan bandi (saluran dengan panjang gelombang lebih pendek); $L_{j}$ adalah nilai reflektan bandj (saluran dengan panjang gelombang lebih panjang); $\sigma_{i i}$ adalah ragam atau varian badn $i$ (saluran dengan panjang gelombang lebih pendek); $\sigma_{j j}$ adalah ragam atau varian band $j$ (saluran dengan panjang gelombang lebih panjang); $\sigma_{i j}$ adalah peragam atau covarian band $i$ dan $j$; dan $k i / k j$ adalah rasio koefisien atenuasi band $i$ dan $j$.

\subsection{Klasifikasi Citra}

Pengelompokan nilai pantulan dari setiap objek perairan dangkal ke dalam kelaskelas tertentu dilakukan dengan metode klasifikasi terbimbing (supervised classification) maximum likelihood. Prinsip maximum likelihood adalah mengkelaskan nilai piksel berdasarkan probabilitas suatu nilai piksel terhadap kelas tertentu dalam sampel piksel (BIG, 2014). Dalam penelitian ini menggunakan 3 kelas habitat perairan dangkal, yaitu pasir, lamun, dan karang mati.Penilaian akurasi atau uji akurasi kemudian dilakukan untuk mengevaluasi efektivitas klasifikasi.

\subsection{Survey Lapangan}

Data lapangan direkam secara stratified random sampling. Pengambilan posisi titik pengamatan direkam menggunakan alat GPS (Global Posittioning System) dengan mengacu pada prinsip penutupan lahan dominan untuk membuat skema klasifikasi daerah pengamatan (Gambar 1). Sampel tutupan objek dasar perairan dangkal yang diperoleh selanjutnya digunakan untuk proses klasifikasi citra secara digital berdasarkan nilai spektral dari masing-masing katagori yang dibuat. Jumlah titik sampel yang diambil adalah sebanyak 319 titik, dimana 114 sebagai input klasifikasi dan 205 titik sebagai input uji akurasi.

\subsection{Uji Akurasi Klasifikasi Citra}

Perhitungan analisis ketelitian data dari masing-masing citra dilakukan dengan membuat tabel matrik kesalahan yang dikenal denganconfusion matrix (Tabel 2). Ada tiga katagori akurasi yang diperoleh dari confusion matrix yaitu akurasi pembuat (producer accuracy), akurasi pengguna (user accuracy), dan akurasi keseluruhan(overall accuracy)(Congalton and Green,2009).Berdasarkan pada SNI 7716:2011, nilai akurasi yang dapat diterima untuk pemetaan habitat dasar perairan laut dangkal adalah sebesar $\geq 60 \%$ (LIPI, 2014). 
Tabel 2. Model Confusion Matrix

\begin{tabular}{ccccccc}
\hline \multicolumn{7}{c}{ Data Lapangan } \\
\hline Hasil Klasifikasi & $\mathrm{A}$ & $\mathrm{B}$ & $\mathrm{C}$ & $\mathrm{D}$ & Jumlah & Producer's Accuracy \\
\hline $\mathrm{A}$ & $\mathrm{X}_{11}$ & $\mathrm{X}_{12}$ & $\mathrm{X}_{13}$ & $\mathrm{X}_{14}$ & $\mathrm{X}_{1+}$ & $\mathrm{X}_{11} / \mathrm{X}_{1+}$ \\
$\mathrm{B}$ & $\mathrm{X}_{21}$ & $\mathrm{X}_{22}$ & $\mathrm{X}_{23}$ & $\mathrm{X}_{24}$ & $\mathrm{X}_{2+}$ & $\mathrm{X}_{22} / \mathrm{X}_{2+}$ \\
$\mathrm{C}$ & $\mathrm{X}_{31}$ & $\mathrm{X}_{32}$ & $\mathrm{X}_{33}$ & $\mathrm{X}_{34}$ & $\mathrm{X}_{3+}$ & $\mathrm{X}_{33} / \mathrm{X}_{3+}$ \\
$\mathrm{D}$ & $\mathrm{X}_{41}$ & $\mathrm{X}_{42}$ & $\mathrm{X}_{43}$ & $\mathrm{X}_{44}$ & $\mathrm{X}_{4+}$ & $\mathrm{X}_{44} / \mathrm{X}_{4+}$ \\
\hline Jumlah & $\mathrm{X}_{+1}$ & $\mathrm{X}_{+2}$ & $\mathrm{X}_{+3}$ & $\mathrm{X}_{+4}$ & $\mathrm{~N}$ & \\
\hline User's Accuracy & $\mathrm{X}_{11} / \mathrm{X}_{+1}$ & $\mathrm{X}_{22} / \mathrm{X}_{+2}$ & $\mathrm{X}_{33} / \mathrm{X}_{+3}$ & $\mathrm{X}_{44} / \mathrm{X}_{+4}$ & & \\
\hline
\end{tabular}

Secara matematis ketiga uji ketelitian data di atas dapat dinyatakan sebagai berikut:

$$
\begin{aligned}
& \text { Producer accuracy }=\frac{X_{i i}}{X_{i+}} \times 100 \% \\
& \text { User accuracy }=\frac{X_{i i}}{X_{+i}} \times 100 \% \\
& \text { Overall accuracy }=\frac{\sum_{i=1}^{n} X_{i i}}{N} \times 100 \%
\end{aligned}
$$

Dimana $N$ adalah jumlah semua piksel yang digunakan untuk pengamatan; $X_{i i}$ adalah nilai diagonal dari matriks kontingensi baris ke- $i$ dan kolom ke- $i ; X_{+i}$ adalah jumlah piksel dalam kolom ke- $i ; X_{i+}$ adalah jumlah piksel dalam baris ke-i. Uji akurasi keseluruhan (overal accuracy) umumnya terlalu over estimate, sehingga dalam menghitung akurasi dianjurkan menggunnakan akurasi kappa atau indeks kappa (Jaya, 2010). Adapun algoritma dari akurasi Kappa ini, yaitu sebagai berikut.

Kappa accuracy $=\frac{N \sum_{i=1}^{r} X_{i i}-\sum_{i=1}^{r} X_{i+}+X_{+i}}{N^{2}-\sum_{i=1}^{r} X_{i+1} X_{+i}} \times 100$

\section{HASIL DAN PEMBAHASAN}

\subsection{Klasifikasi Citra Digital}

Sebaran dan kondisi penutupan dasar perairan dangkal di kawasan perairan Tanjung Benoa, Bali dapat diketahui melalui nilai luasan objek hasil analisis citra terklasifikasi. Berdasarkan hasil interpretasi dari masingmasing citra terdapat 3 kelas objek habitat dasar perairan dangkal diantaranya karang mati, lamun, dan pasir (Gambar 2 dan 3).

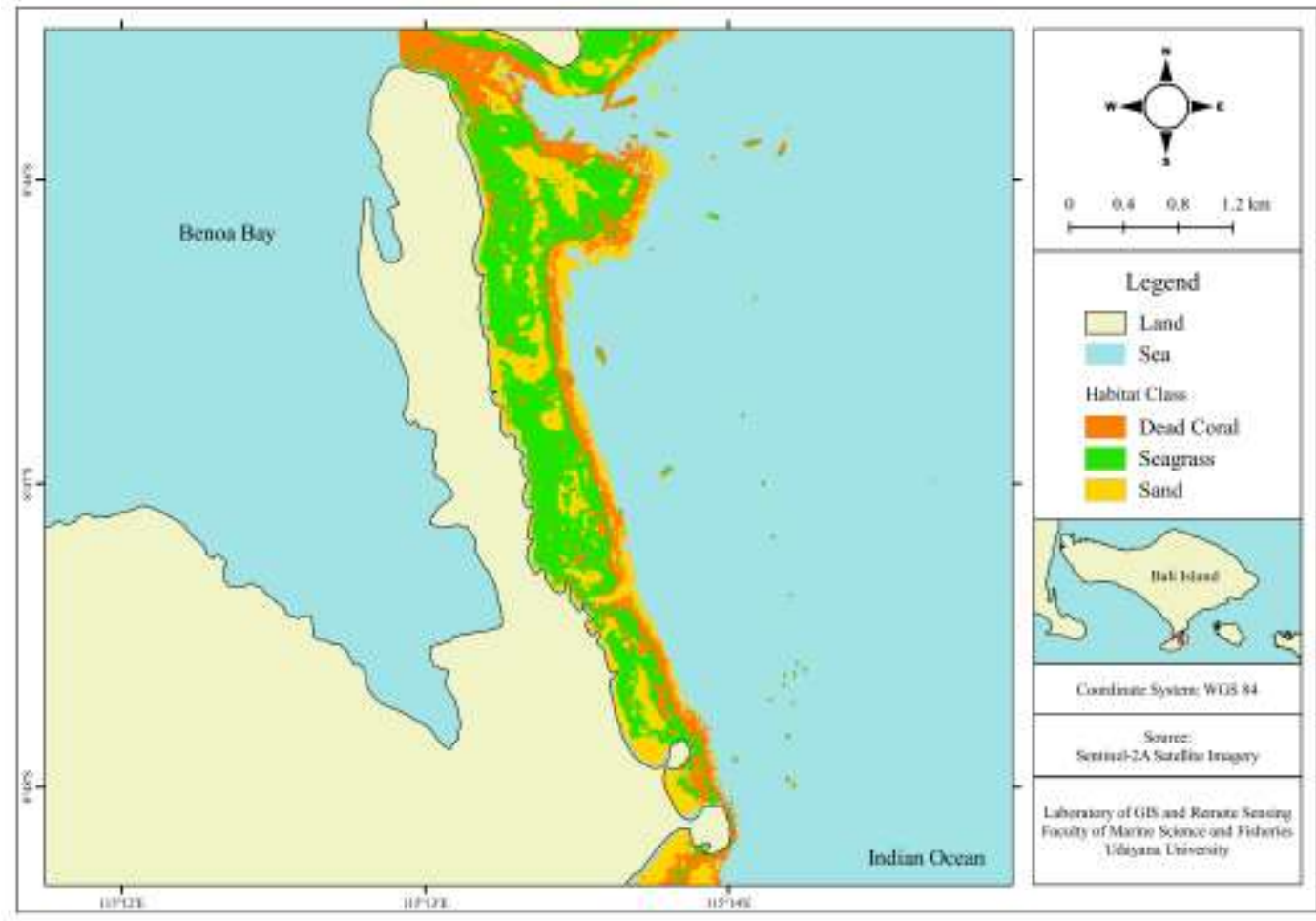

Gambar 2.

Klasifikasi Citra Sentinel-2A 


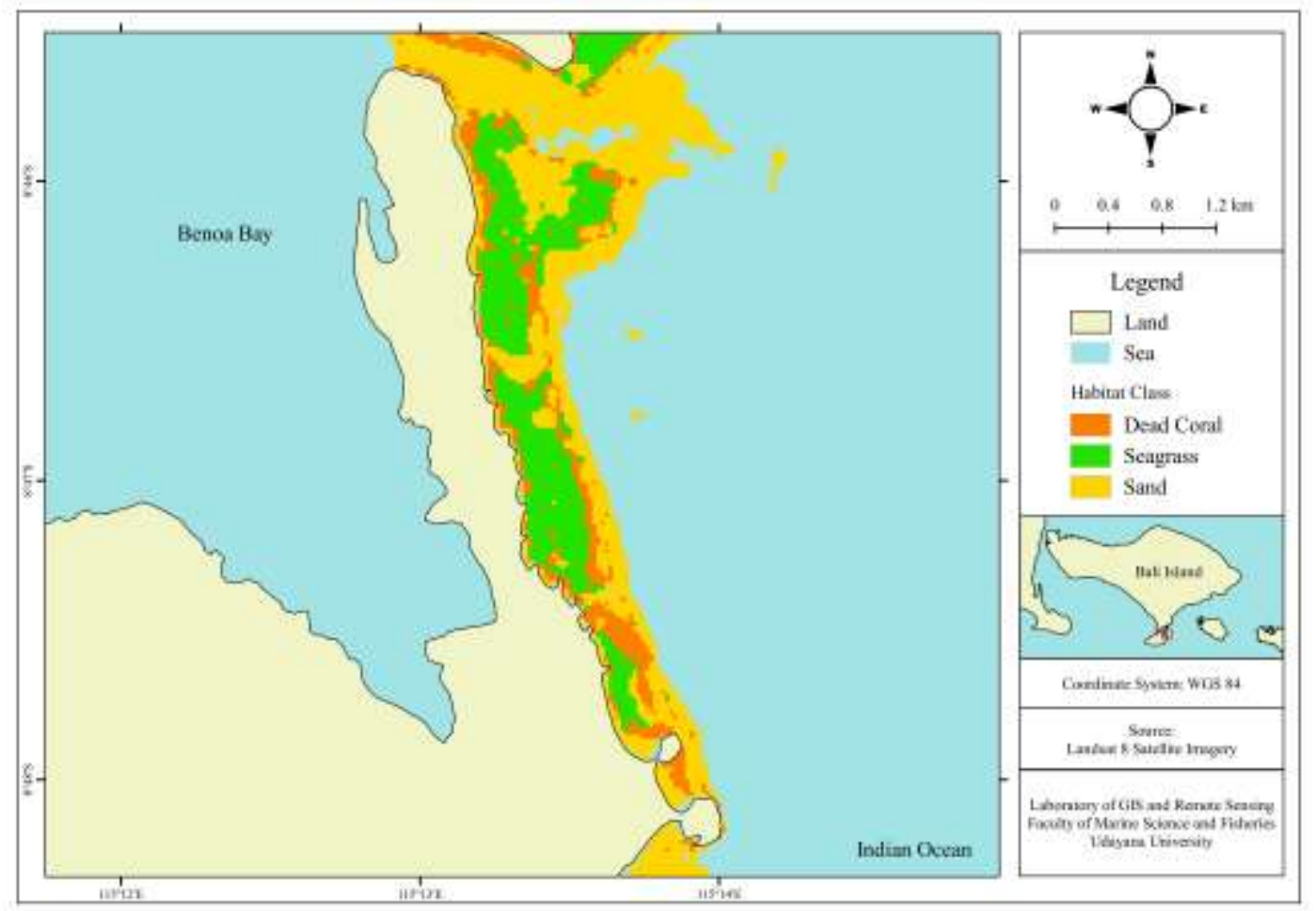

Gambar 3.

Klasifikasi Citra Landsat 8

Dari ketiga kelas habitat tersebut, kelas karang mati merupakan habitat yang memiliki luasan yang paling kecil diantara kelas habitat lainnya, dengan luas sebesar 109.71 ha (24\%) untuk hasil klasifikasi citra Sentinel-2A dan 79,37 ha $(15 \%)$ untukhasil klasifikasi citra Landsat 8. Sementara itu, hasil yang berbeda didapatkan pada luasan kelas habitat yang paling tinggi, dimana pada hasil klasifikasi citra Sentinel-2A menunjukkan habitat lamun sebagai habitat yang memiliki luasan yang paling tingi, yaitu sebesar 203.91 ha (45\%). Sedangkan untuk hasil klasifikasi citra Landsat 8 mendapatkan subtrat pasir sebagai habitat yang memiliki luasan yang paling tinggi, yaitu sebesar 301,80 ha (57\%).

Dari hasil luas area klasifikasi masingmasing citra diketahuibahwa citra Landsat 8 mampu menghasilkan luasan area habitat dasar perairan dangkal yang lebih luas dibandingkan dengan citra Sentinel-2A. Hal tersebut menandakan bahwa citra Landsat 8 memiliki kemampuan penetrasi kolom perairan yang lebih baik dari citra Sentinel-2A (Gambar 4). Berikut merupakan luas area klasifikasi dari masing-masing citra satelit yang tertera pada Tabel 3 .

Tabel 3. Luasan Area Klasifikasi Citra

\begin{tabular}{ccccc}
\hline \multirow{2}{*}{ Kelas Habitat } & \multicolumn{2}{c}{ Citra Landsat 8 } & \multicolumn{2}{c}{ Citra Sentinel-2A } \\
\cline { 2 - 5 } & Luasan (ha) & Persentase (\%) & Luasan (ha) & Persentase (\%) \\
\hline Karang Mati & 79,37 & $15 \%$ & 109,71 & $24 \%$ \\
Lamun & 145,93 & $28 \%$ & 203,91 & $45 \%$ \\
Pasir & 301,80 & $57 \%$ & 138,33 & $31 \%$ \\
\hline Total & 527,10 & $100 \%$ & 451,95 & $100 \%$ \\
\hline
\end{tabular}



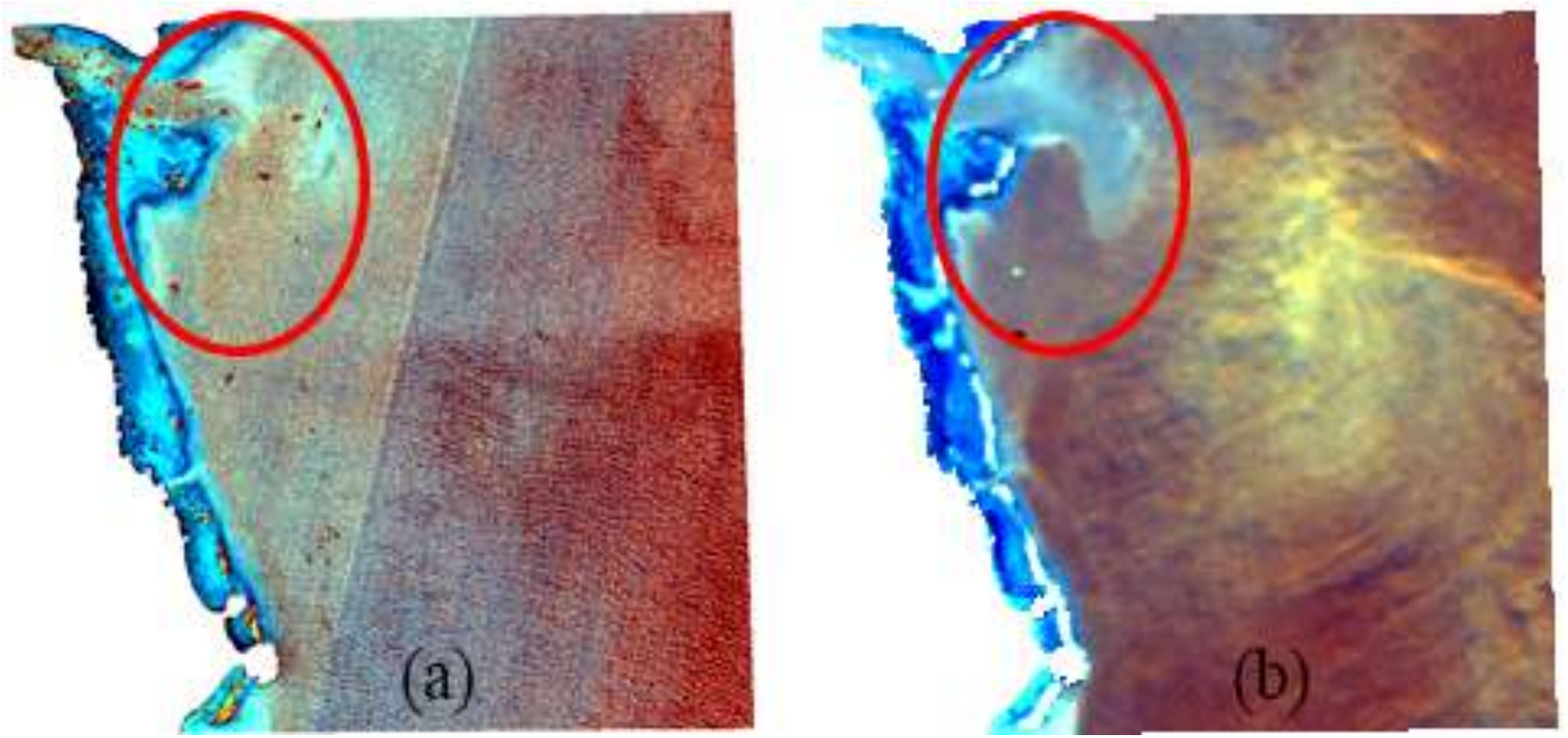

Gambar 4.

Citra Hasil Koreksi Kolom Air, (a) Citra Sentinel-2A, (b) Citra Landsat 8. Lingkaran Merah Merupakan Area dengan Perbedaan Penetrasi Kedalaman Perairan yang Signifikan dari Kedua Citra.

\subsection{Evaluasi Akurasi Klasifikasi Objek Bawah Air Perairan Laut Dangkal}

Secara umum uji akurasi pada kedua citra menunjukkan akurasi citra Sentinel-2A lebih tinggi dari citra Landsat 8 dengan akurasi keseluruhan (overall accuracy) dan akurasi kappa pada citra Sentinel-2A sebesar 80,00\% dan $59,27 \%$ sementara citra Landsat 8 memiliki akurasi keseluruhan (overall accuracy) sebesar 68,29\% dan akurasi kappa sebesar $35,43 \%$. Evaluasi akurasi pembuat (producer accuracy) citra Sentinel-2A menunjukkan kelas lamun memiliki akurasi tertinggi yakni sebesar $85,06 \%$, sementara akurasi terendah dimiliki oleh kelas karang mati dengan akurasi sebesar 10,00\%.Begitu pula pada hasil perhitungan akurasi pengguna (user accuracy), dimana kelas lamun memiliki akurasi tertinggi dengan akurasi sebesar 91,36\% dan terendah pada kelas karang mati, yaitu $8,33 \%$. Pada citra Landsat 8, akurasi pembuat (producer accuracy) menunjukkan pola yang sama seperti citra Sentinel-2A, tetapi memiliki akurasi yang lebih tinggi dibandingkan citra Sentinel-2A. Sedangkan pada perhitungan akurasi pengguna (user accuracy) pada citra Landsat 8 memperoleh hasil yang berbeda seperti hasil uji akurasicitra Sentinel-2A, dimana akurasi pengguna tertinggi terdapat pada kelas karang mati dengan nilai akurasi sebesar 75,00\% kemudian diikuti kelas lamun sebesar 70,37\% dan kelas pasir sebesar 54,84\% (Tabel 3 dan 4).

Tabel 3. Evaluasi Klasifikasi Citra Sentinel-2 A

\begin{tabular}{cccccc} 
Hasil Klasifikasi & \multicolumn{3}{c}{ Data Lapangan } & \multirow{2}{*}{ Producer's Accuracy } \\
\cline { 2 - 5 } & Karang Mati & Lamun & Pasir & Total & \\
\hline Karang Mati & 1 & 8 & 1 & 10 & 10,00 \\
Lamun & 11 & 148 & 15 & 174 & 85,06 \\
Pasir & 0 & 6 & 15 & 21 & 71,43 \\
\hline Total & 12 & 162 & 31 & 205 & \\
\hline User's Accuracy & 8,33 & 91,36 & 48,39 \\
\hline Overall Accuracy & \multicolumn{5}{c}{80,00} \\
\hline Kappa Accuracy & \multicolumn{5}{c}{59,27} \\
\hline
\end{tabular}


Tabel 4. Evaluasi Klasifikasi Citra Landsat 8

\begin{tabular}{|c|c|c|c|c|c|}
\hline \multirow{2}{*}{ Hasil Klasifikasi } & \multicolumn{4}{|c|}{ Data Lapangan } & \multirow{2}{*}{ Producer's Accuracy } \\
\hline & Karang Mati & Lamun & Pasir & Total & \\
\hline Karang Mati & 9 & 44 & 8 & 61 & 14,75 \\
\hline Lamun & 3 & 114 & 6 & 123 & 92,68 \\
\hline Pasir & 0 & 4 & 17 & 21 & 80,95 \\
\hline Total & 12 & 162 & 31 & 205 & \\
\hline User's Accuracy & 75,00 & 70,37 & 54,84 & & \\
\hline Overall Accuracy & & & 68,29 & & \\
\hline Kappa Accuracy & & & 35,43 & & \\
\hline
\end{tabular}

Studi pemanfaatan citra satelit Sentinel2A untuk pemetaan habitat perairan laut dangkal sebelumnya pernah dilakukan oleh Prawoto dan Hartono (2018) di perairan Pulau Menjangan Kecil dan Menjangan Besar, Kepulauan Karimunjawa. Penelitian tersebut menggunakan skema klasifikasi 4 kelas dengan metode klasifikasi maximum likelihood yang menghasilkan akurasi keseluruhan (overall accuracy) untuk citra terkoreksi kolom air sebesar 80,73\%. Sedangkan dengan menggunakan citra Landsat 8, Hafizt dkk. (2017) memetakan habitat perairan dangkal di Kepulauan Padaido, Papua mendapatkan hasil akurasi keseluruhan hasil pemetaan sebesar 47,57\%. Rendahnnya nilai akurasi keseluruhan pada penelitian tersebut diakibatkan karena jumlah kelas yang digunakan cukup banyak (7 kelas).

Selain dipengaruhi oleh banyaknya kelas pada proses klasifikasi, tinggi rendahnya nilai akurasi hasil pemetaan juga berkaitan dengan karakteristik citra satellite dari citra satelit yang digunakan, dimana salah satu faktor utama adalah resolusi spasialnya. Sentinel-2A merupakan satelit dengan katagori resolusi spasial tinggi, tiga kali lebih baik dari Landsat 8 . Selain itu, berkurangnya nilai akurasi hasil pemetaan juga dapat diakibatkan oleh beberapa faktor seperti perbedaan waktu pengambilan data lapangan dan perekaman citra yang menyebabkan terjadinya perubahan pola spektral, terdapat kesalahan dalam penentuan training area masing-masing kelas, serta adanya kesalahan dalam mengidentifikasi objek habitat perairan laut dangkal berdasarkan definisi yang digunakan.

\subsection{Persebaran Habitat Objek Bawah Air Perairan Laut Dangkal}

Hasil ground check menunjukkan terdapat tiga tipe penutupan objek bawah air yang berada di kawasan pesisir Tanjung Benoa. Tipe penutupan objek antara lain adalah karang mati, lamun, dan pasir. Tipe penutupan objek pasir tersebar secara acak pada bagian tengah daerah penelitian sementara objek karang berada di daerah pemecah ombak dan terletak jauh dari daratan.Data dari pengamatan lapangan menunjukkan adanya 8 jenis spesies lamun di kawasan pesisir Tanjung Benoa yaitu Cymodocea rotundata, Enhalus acoroides, Halodule pinifolia, Halodule uninervis, Halophila ovalis, Thalassia hemprichi, Syringodium isoetifolium dan Thalassodendron ciliatum. Hasil ini berbeda dengan Elok dkk. (2017) yang menyatakan bahwa terdapat 6 jenis spesies lamun yang berada dikawasan pesisir Tanjung Benoa, yaitu Enhalus acoroides, Thalassia hemprichii, Cymodocea rotundata, Halophila ovalis, Halodule uninervis, Halodule pinifolia. 


\section{SIMPULAN}

Dalam penelitian ini, pemetaan habitat perairan dangkal di perairan padat wisata Tanjung Benoa telah dilakukan dengan menggunakan teknologi remote sensing. Analisis Lyzenga diterapkan pada dua citra satelit optik dengan sensor yang berbeda yaitu Landsat 8 (resolusi spasial $30 \mathrm{~m}$ ) dan citra satellite Sentinel-2A (resolusi spasial $10 \mathrm{~m}$ ). Dari hasil klasifikasi dan uji akurasi dengan skema tiga kelas dapat disimpulkan bahwa kedua citra satelit mampu mengidentifikasi objek bawah air yang terdiri dari karang mati, lamun, dan pasir di prairan dangkal Tanjung Benoa. Uji akurasi menunjukkan kinerja citra Sentinel-2A untuk prediksi objek bawah air lebih baik dari citra Landsat 8 dengan nilai akurasi keseluruhan (overall accuracy) sebesar $80,00 \%$ dan akurasi kappa sebesar $59,27 \%$ untuk citra Sentinel-2A dan nilai akurasi keseluruhan (overall accuracy) sebesar 68,29\% dan akurasi kappa sebesar $35,43 \%$ untuk citra Landsat-8.

\section{DAFTAR PUSTAKA}

Adikusuma, D., Rusadi, E.Y. and Hayuni, N., 2014. Dampak degradasi lingkungan terhadap potensi pengembangan ekowisata berkelanjutan di Delta Mahakam: Suatu tinjauan. Jurnal Wilayah dan Lingkungan, 2(1), pp.11-24.

Arief, M., 2013.Pengembangan Metode Lyzenga untuk Deteksi Terumbu Karang di Kepulauan Seribu dengan Menggunakan Data Satelit AVNIR2. STATISTIKA: Journal of Theoretical Statistics and Its Applications, 13(2), pp.55-64.

Badan Informasi Geospasial (BIG), 2014. Peraturan Kepala Badan Informasi Geospasial No. 3 Tentang Pedoman Teknis Pengumpulan dan Pengolahan Data Geospasial Objek Perairan Bawah Laut Perairan Laut Dangkal. Cibinong, Indonesia.
Badan Pusat Statistik Provinsi Bali (BPS), 2018. Statistik Wisatawan Mancanegara Ke Bali 2018. Bali, Indonesia.

Bato, M., Yulianda, F. and Fahruddin, A., 2013. Kajian manfaat kawasan konservasi perairan bagi pengembangan ekowisata bahari: Studi kasus di kawasan konservasi perairan Nusa Penida, Bali. DEPIK Jurnal Ilmu-Ilmu Perairan, Pesisir dan Perikanan, 2(2).

Congalton, R.G., \&Green, K., 2009. Assessing the Accuracy of Remotely Sensed Data: Principles and Practices. New York (US), CRC Press.

Congedo, L., 2016. Semi-automatic classification plugin documentation. Release, 4(0.1), 29.

Darmono, 2001. Lingkungan Hidup dan Pencemaran. Jakarta, Inodonesia.

European Space Agency (ESA), 2015. SENTINEL-2 User Handbook. Esa Standard Document. 64 hal.

Faiqoh, E., Wiyanto, D.B. and Astrawan, I.G.B., 2017. Peranan Padang Lamun Selatan Bali Sebagai Pendukung Kelimpahan Ikan di Perairan Bali. Journal of Marine and Aquatic Sciences, 3(1), pp.10-18.

Graha, Y.I., Arthana, I.W. and Karang, I.W.G.A., 2016. Simpanan karbon padang lamun di kawasan pantai sanur, kota denpasar. Ecotrophic: Journal of Environmental Science, 10(1), pp.46-53.

Hafizt, M., Manessa, M.D.M., Adi, N.S., Prayudha, B., 2017. Benthic Habitat Mapping by Combining Lyzenga's Optical Model and Relative Water Depth Model in Lintea Island, Southeast Sulawesi.The 5th Geoinformation Science Symposium, IOP Conference Series: Earth and Environmental Science 98. 012037. doi:10.1088/17551315/98/1/012037.

Jaya, I.N.S., 2010. Analisis Citra Digital, Perspektif Penginderaan Jauh untuk Pengelolaan Sumber Daya Alam. Fakultas Kehutanan. Bogor (ID): Institut Pertanian Bogor. 
Khrisnamurti, K., Utami, H., \& Darmawan, R., 2017. Dampak Pariwisata terhadap Lingkungan di Pulau Tidung Kepulauan Seribu. Kajian, 21(3), 257-273.

Lembaga Ilmu Pengetahuan Indonesia (LIPI), 2014.Panduan Teknis Pemetaan Habitat Dasar Perairan Laut Dangkal. Jakarta, Indonesia.

Lyzenga, D.R., 1981. Remote sensing of bottom reflectance and water attenuation parameters in shallow water using aircraft and Landsat data. International journal of remote sensing, 2(1), pp.71-82.

McFeeters, S., 2013. Using the normalized difference water index (NDWI) within a geographic information system to detect swimming pools for mosquito abatement: A practical approach. Remote Sensing, 5(7), pp.3544-3561.

Nurdin, N., Hidayatullah, T. and AS, M.A., 2016. Analisis Klasifikasi Objek Penutup Dasar Perairan Laut Dangkal Menggunakan Citra Alos Avnir2. Majalah Ilmiah Globe, 11(1).

Prawoto, C.D., Hartono, 2018. Pemetaan Habitat Bentik dengan Citra Multispektral Sentinel-2A Di Perairan Pulau Menjangan Kecil Dan Menjangan Besar, Kepulauan Karimunjawa.Jurnal Bumi Indonesia, 7 (3).
Putra, A. and Husrin, S., 2017. Kualitas Perairan Pasca Cemaran Sampah Laut Di Pantai Kuta Bali Water Quality of Post Contamination Of Marine Debris In The Kuta Beach Of Bali. Jurnal Ilmu dan Teknologi Kelautan Tropis, 9(1), pp.5766.

Rahadiarta, I.K.V.S., Putra, I.D.N.N. and Suteja, Y., 2019. Simpanan Karbon Pada Padang Lamun di Kawasan Pantai Mengiat, Nusa Dua Bali. Journal of Marine and Aquatic Sciences, 5(1), pp.110.

Siregar, V., 2010.Pemetaan substrat dasar perairan dangkal karang congkak dan lebar kepulauan seribu menggunakan citra satelit quickbird. E-Jurnal Itkt, 2, pp.19-30.

Suwargana, N. and Jauh-LAPAN, P.P.P., 2014. Analisis Citra Alos Avnir-2 untuk Pemetaan Terumbu Karang (Studi Kasus: Banyuputih, Kabupaten Situbondo. Deteksi Parameter Geobiofisik dan Diseminasi Penginderaan Jauh, pp.588596.

United States Geological Survey (USGS), 2016.LANDSAT 8 (L8) DATA USERS HANDBOOK. Version 2.0 March 29, 2016. 98 hal. 